V.F. Syvokobylenko, V.A. Lysenko

\title{
MULTIFREQUENCY PROTECTING METHOD AGAINST EARTH-FAULTS OF PHASE IN THE COMPENSATED ELECTRIC NETWORKS
}

Introduction. A significant proportion of earth faults in 6 - $35 \mathrm{kV}$ networks is a transient and short-lived process, which is followed by an electric arc. Problem. In such cases, earth-fault protection that responds to steady-state current and voltage is not able to operate properly. Also, the use of the Petersen coil to compensate for the capacitive earth fault current complicates the protection function because it significantly reduces the single phase earth fault current in steady state. Purpose. To develop selective single-phase earth faults protection algorithm using harmonic components that occur in zero-sequence currents and voltage in the transient process. Method. A mathematical model of the power supply system is applied to study the frequency components of currents and voltage of zero sequence in compensated electrical networks with phase-to-earth faults, and a mathematical model is used to test the operation of the developed protection algorithm. The results showed that, the reactive power for harmonic components of the frequency greater than $100 \mathrm{~Hz}$, which are separated from the current and voltage of zero sequence in compensated electrical networks on the damaged feeder, is positive regardless of the degree of compensation of the capacitive current. That may be the basis of the principle of directional protection. Originality. Phase-to-earth fault selective protection algorithm has been developed. In that algorithm, first derivatives of currents and voltages of zero sequence are found, to reduce the influence of aperiodic components. And then, by using of the Fourier transform, a number of harmonic orthogonal components are extracted from them. Reactive power is calculated for each of frequency component and their total sum is found. If that sum excess of threshold, the relay will make a decision. The reliability of the developed protection algorithm is confirmed by the results of mathematical modeling and verification of the test sample at the laboratory stand and by means of field signals that were recorded by digital loggers at the substations. References 10, table 1, figures 6.

Key words: electrical network, earth fault protection, zero sequence current and voltage, Fourier transform, frequency spectrum.

За допомогою математичної моделі компенсованої електричної мережі виконано аналіз струмів $і$ напруг нульової послідовності при замиканнях фази на землю і показано, що в них під час перехідного процесу виникають вищі гармонійні складові, які обумовлені розрядом ємностей ушкодженої фази, дозарядом ємностей неушкоджених фаз, а також зростанням струму реактора в нейтралі мережі. Показано, що незалежнно від ступеня компенсації реактором ємнісного струму промислової частоти, реактивна потужність для гармонічних складових струмів $i$ напруг 3 частотою в два рази і більше промислової, є додатною для ушкодженого приєднання і від'ємною для неушкоджених. Це прийнято за основу в розробленому методі захисту направленої дї̈, в якому при замиканнях рази на землю спочатку визначають похідні струмів $і$ напруг нульової послідовності, щчо зменшує вплив аперіодични складових $i$ підсилює складові вищих гармонік, а потім за допомогою перетворення Фур'є знаходять комплексні значення для ряду найбільш впливових гармонійних складових, більших за першу. За допомогою отриманих складових струмів і напруг для кожної частоти знаходять реактивну потужність, $і$ якщчо їх сума перевищує задану, то спрацьовує вихідний орган захисту. Достовірність розробленого методу захисту підтверджсено результатами математичного моделювання і перевіркою роботи дослідного зразка на лабораторному стенді. Бібл. 10, табл. 1, рис. 6.

Ключові слова: електрична мережа, захист від замикань на землю, струм і напруга нульової послідовності, перетворення Фур'є, частотний спектр.

С помощью математической модели компенсированной электрической сети выполнен анализ токов и напряжений нулевой последовательности при замыканиях фазы на землю и показано, что у них во время переходного процесса возникают высшие гармонические составляющие, которые обусловлены разрядом емкостей поврежденной фазы, дозарядом емкостей неповрежденных фаз, а также ростом тока реактора в нейтрале сети. Показано, что независимо от степени компенсации реактором емкостного тока для промышленной частоты, реактивная мощность, рассчитанная для выделенных гармонических составляющих токов и напряжений с частотой в два раза и более промышленной, положительная для поврежденного присоединения и отрицательная для неповрежденных. Это принято за основу в разработанной защите направленного действия, в которой при замыканиях фазы на землю сначала определяют производные токов и напряжений нулевой последовательности, что уменьщает влияние апериодических составляющих и усиливает гармонические составляющие, а затем с помощью преобразования Фурье находят комплексные значения для ряда наиболее влиятельных гармонических составляющих, больщих первой. С помощью полученных составляющих токов и напряэений для каждой частоты находят реактивную мощность, и если их сумма превышает заданную, то срабатывает выходной орган защиты. Достоверность разработанной защиты подтверждена результатами математического моделирования и проверкой работы опытного образца на лабораторном стенде. Библ. 10, табл. 1, рис. 6.

Ключевые слова: электрическая сеть, защита от замыканий на землю, ток и напряжение нулевой последовательности, преобразования Фурье, частотный спектр.

The relevance of the problem and its relation to the applied tasks. $6-10 \mathrm{kV}$ electrical networks operating in the grounded neutral mode are the basis of power supply systems for industrial enterprises, power plants, cities. Given the large length and widespread of such networks, the problem of protecting networks from the most common damage of insulation - single-phase earth faulting - is urgent. A large proportion of earth faults is a transient and short-term process that is accompanied by an electric arc. In such cases, a ground fault protection device that responds to steady-state current and voltage is 
not able to operate properly. Also, the use of the Petersen coil to compensate for the capacitive earth fault current complicates the operation of the protection devices as it significantly reduces the single-phase earth fault current in steady state.

Review of publications and shortcomings of known solutions. The problem of the analysis of transients in networks with earthed neutral in order to create an effective algorithm for protection against unstable earth faults is being actively investigated in Europe and around the world [1-3]. In particular, the work [3] investigates the aperiodic component of the transient of a single-phase earth fault and analyzes its influence on the work of known methods of protection against such earth fault. Much attention is paid to the peculiarities of mathematical modelling of the electric arc in the place of damage and methods of classification of different types of damage $[4,5]$. In [6], methods of filtering the signals of current and voltage sensors are investigated, and attention is paid to testing them using real signals recorded by the logger at an operating substation. In [7], methods for the identification of single-phase earth faults are developed and the sensitivity of such methods under conditions of high resistance at the fault location is analyzed. Mathematical models of electrical networks are studied, which also include models of relay protection devices $[8,9]$. The search for optimal parameters of mathematical methods of signal processing of primary sensors and settings for the operation of systems of protection against single-phase earth fault $[6,10]$ is carried out. There are also known attempts to use different types of neural network-type «black box» methods to protect against single-phase earth-faulting, but in our opinion, the simpler approaches are not exhausted, the most attractive being the analysis and use of different frequency components in currents $\left(3 i_{0}\right)$ and the voltage $\left(3 u_{0}\right)$ of the zero sequence.

The goal of investigation. Using a mathematical model to study the harmonic composition of currents and voltages of zero sequence in compensated electrical networks at phase-to-earth faults and to develop a method of selective protection by using harmonic components that occur in currents and voltages of zero sequence in transients.

Main material and results obtained. In works $[8,9]$, for selective protection against phase-to-earth short circuits, it is proposed to use frequency filters to select from the zero sequence current $3 i_{0}$ and zero sequence voltage $3 u_{0}$ components of one of the frequencies, for example, 200 or $300 \mathrm{~Hz}$ and to provide selectivity of the protection operation in the direction of the calculated reactive power the effect on which of the reactor at these frequencies is significantly attenuated. In this paper, to increase the sensitivity of the protection, we consider the possibility of the simultaneous use of currents and voltages for several frequencies found through the Fourier transform.

To study the harmonic composition of the currents $3 i_{0}$ and the voltage $3 u_{0}$ of the zero sequence, we use the mathematical model described in [8]. We apply it, for example, to a compensated electrical network consisting of a $110 \mathrm{kV}$ transmission line, a step-down transformer, which is connected to a $6 \mathrm{kV}$ section with three cable lines, phase capacities in each of which are respectively $3.8 \mu \mathrm{F}$ and $12 \mu \mathrm{F}$. The network neutral is grounded through a reactor with a resonant inductance of $0.142 \mathrm{H}$. The results of simulation of deaf and arc single-phase earth fault (SEF) under different modes of reactor tuning showed that the currents $3 i_{0}$ and voltage $3 u_{0}$ at the beginning of the transient contain aperiodic and periodic components with different damping constants which are caused by discharge of capacities of damaged phases, recharge of capacities of intact phases as well as an increase in reactor current in network neutral. The duration of this transient is approximately the period of power frequency $(20 \mathrm{~ms})$. Comparison of the Fourier spectra for the currents $3 i_{0}$ and voltages $3 u_{0}$, as well as for their derivatives $p\left(3 i_{0}\right)$ and $p\left(3 u_{0}\right)$, showed that the harmonic amplitudes and the calculated values of the reactive power by means of the derivatives are almost an order of magnitude greater and are expedient to use their in protection. The nature of the change in time of the derivatives of the current and the voltage of the zero sequence at SEF is shown in Fig. 1. The differentiation operation significantly reduces the aperiodic components and enhances the higher frequency components. The numerical calculation of the orthogonal component of signals using the derivatives $p\left(3 i_{0}\right)$ and $p\left(3 u_{0}\right)$ is performed by (1) for three discrete instantaneous values of current (voltage) $x_{n-2}, x_{n-1}, x_{n}$ for the step of calculation, for example $h=0.625 \mathrm{~ms}$ and for frequency $\omega=314 \mathrm{~s}^{-1}$.

$$
\frac{d}{d t}(x)=p x=\frac{1}{2 \omega h}\left(3 x_{n-2}-4 x_{n-1}+x_{n}\right) .
$$

The Fourier spectrum (Fig. 2) is calculated for the data shown in Fig. 1 and from which an array of $N=32$ discrete elements is formed over time of $0.02 \mathrm{~s}$.
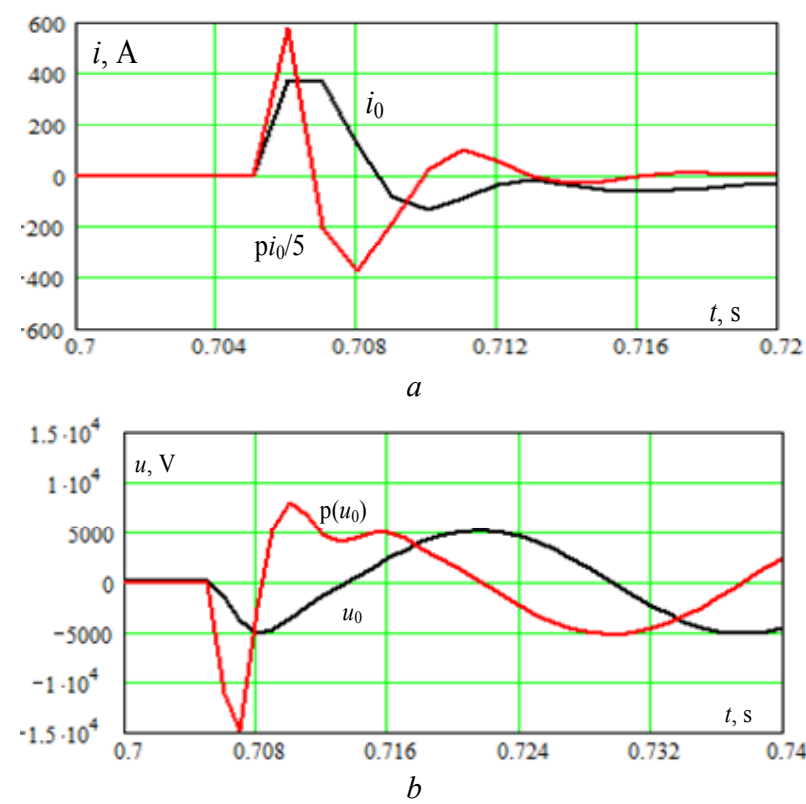

Fig. 1. Nature of the change in time of the zero sequence current and the derivative of this current $(a)$, the voltage of the zero

sequence and the derivative of this voltage $(b)$ at SEF

From the numerical data obtained using the $f f t(y)$ function of MathCAD and shown in Fig. 2, it follows that the most influential harmonics are in the frequency range of $150-500 \mathrm{~Hz}$. 


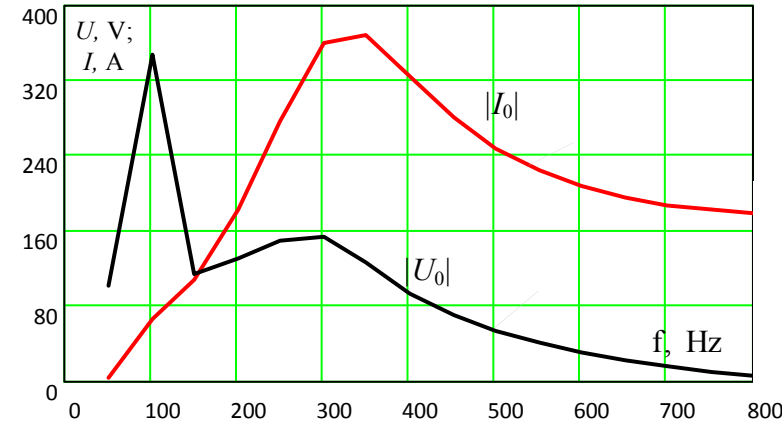

Fig. 2. Fourier spectrum for current and voltage derivatives of the zero sequence at SEF

The calculations for each $k$-th harmonic of reactive power using the complex values of currents and voltages obtained by the Fourier transform are performed according to the expressions (2):

$$
\begin{aligned}
& q_{k}=i_{\alpha k} \cdot u_{\beta k}-i_{\beta k} \cdot u_{\alpha k} ; \\
& p\left(\overrightarrow{i_{0}}\right)_{k}=i_{\alpha k}-j i_{\beta k} ; \\
& p\left(\overrightarrow{u_{0}}\right)_{k}=u_{\alpha k}+j u_{\beta k} .
\end{aligned}
$$

The results of the calculation using the Fourier transform of the amplitudes of currents and voltages, reactive and active powers for the harmonics of multiples of the first one $\left(f_{0}=50 \mathrm{~Hz}\right)$ in the range from 1 to 9 are shown in Table 1.

The data (Table 1) are shown for the reactor resonance tuning mode. According to these data, it is advisable to use for the protection harmonics with multiplicities 3, 4, 5, 6, for which the reactive power values are maximum. Calculations for reactor overcompensation modes have shown that the reactive power for harmonics 1, 2 can be negative and therefore it is undesirable to use these harmonics.

Table 1

Results of the calculation of reactive and active powers and amplitudes of harmonic components for derivatives of currents and voltages

\begin{tabular}{|c|c|c|c|c|}
\hline$f l f_{0}$ & $I, \mathrm{~A}$ & $U, \mathrm{~V}$ & $Q, \mathrm{kVA}$ & $P, \mathrm{~kW}$ \\
\hline 1 & 66.15 & 5196 & 226 & -259 \\
\hline 2 & 106.6 & 1715 & 182.8 & 3.058 \\
\hline 3 & 181.3 & 1957 & 354.5 & 11.22 \\
\hline 4 & 277.0 & 2234 & 618.8 & 6.941 \\
\hline 5 & 360.0 & 2287 & 822.7 & -37.46 \\
\hline 6 & 367.4 & 1900 & 692 & -95.31 \\
\hline 7 & 324.0 & 1406 & 441 & -11.32 \\
\hline 8 & 280.0 & 1044 & 273 & -104 \\
\hline 9 & 246.0 & 796 & 177 & -85.48 \\
\hline
\end{tabular}

Based on the obtained calculation data, a method of selective protection was developed, the block diagram of the algorithm of which is shown in Fig. 3 and in which there are: analog-to-digital converters - ADC, Fourier transform units - FFT, units of determination of derivatives $-\mathrm{d} / \mathrm{dt}$, multiplication units $-\mathrm{X}$, summation unit $-\Sigma$, comparators for comparison of voltage amplitudes $3 u_{0}$ with set value for frequency $50 \mathrm{~Hz}$ and the total reactive power $Q_{T}$ for selected harmonics with set value $U_{T}$, logic elements $\mathrm{OR}, \mathrm{AND}$, as well as the output organ Relay.

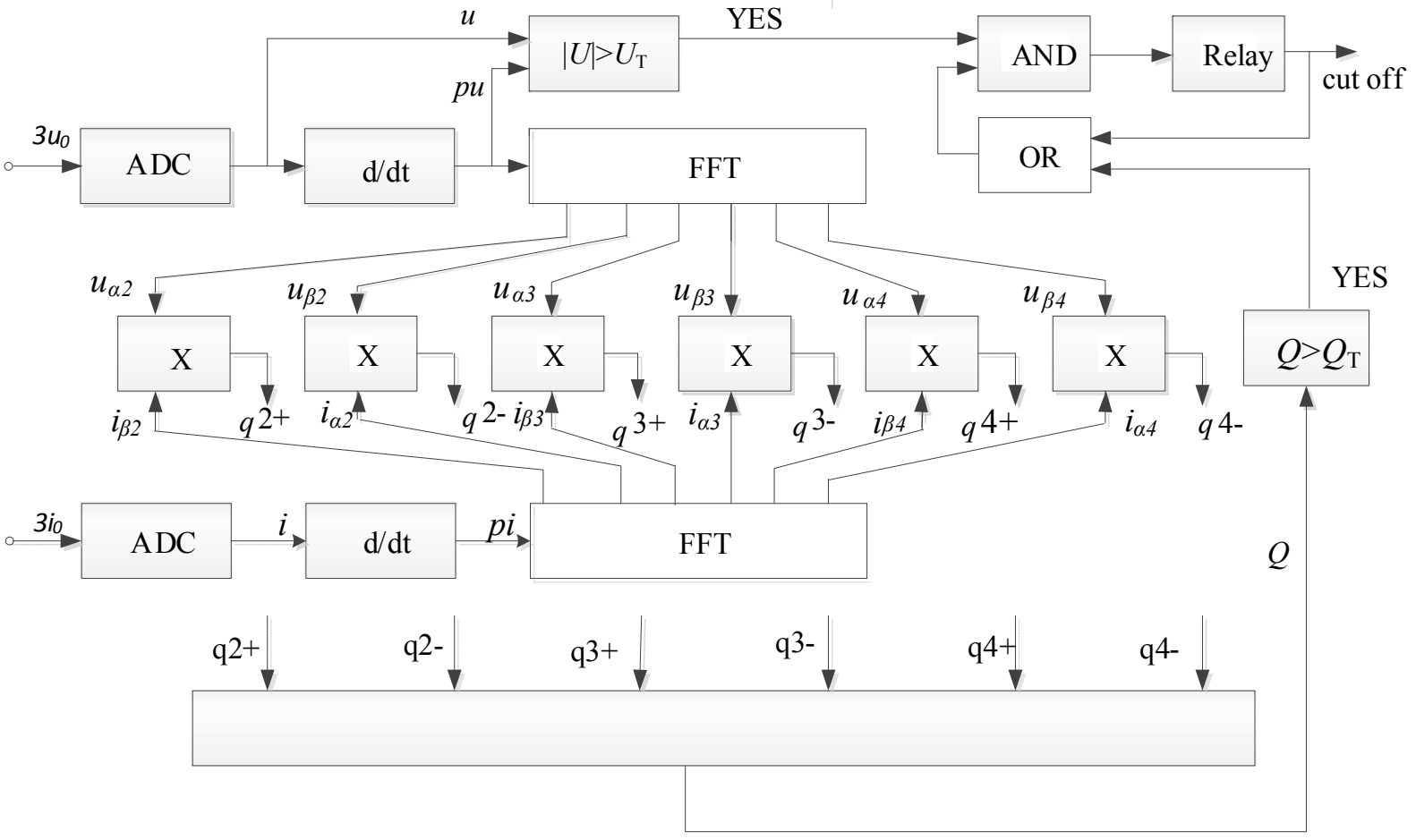

Fig. 3. Block diagram of the multifrequency method of selective earth-fault protection in compensated networks

The actuation organ is triggered if the voltage amplitude $3 u_{0}$ exceeds the set value $U_{T}$ which is $10-15 \%$ of the nominal value. The amplitude of this voltage is calculated from the orthogonal components that are obtained from the ADC and $\mathrm{d} / \mathrm{dt}$ units and then calculated as $\sqrt{u_{n}^{2}+\left(p u_{n}\right)^{2}}$.

The relay input signals - the current $3 i_{0}$ and voltage $3 u_{0}$ after $\mathrm{ADC}$ and $\mathrm{d} / \mathrm{dt}$ differentiation units are fed to the Fourier transform units in which for given frequencies $f_{2}-$ 
$f_{n}$ complex values of harmonic components for currents (sine $i_{\beta 2}, i_{\beta 3}, \ldots$ and cosine $i_{\alpha 2}, i_{\alpha 3}, \ldots$ ) and for voltages (sine $u_{\beta 2}, u_{\beta 3}, \ldots$ and cosine $u_{\alpha 2}, u_{\alpha 3}, \ldots$ ) are calculated. Based on these values for each of the frequencies, in the respective units of multiplication $\mathrm{X}$ the positive $\left(q^{+}\right)$and negative $\left(q^{-}\right)$values of the reactive power are calculated. For each frequency they are found as:

$$
q^{+}=u_{\beta} \cdot i_{\alpha} ; \quad q^{-}=u_{\alpha} \cdot i_{\beta} ; \quad q=q^{+}-q^{-} .
$$

In the general mathematical model of the compensated electrical system and the protection relay, a software module for the implementation of the Fourier transform and the determination of the total reactive power of the higher harmonics $f$ (the third through the sixth ones) are shown in Fig. 4.

$$
\begin{aligned}
& F u r(F I, F U):=\mid \begin{array}{l}
I \leftarrow F I \\
U \leftarrow F U
\end{array} \\
& \begin{array}{l}
U \leftarrow F U \\
N \leftarrow \operatorname{rows}(U)
\end{array} \\
& \text { for } f \in 3 . .6 \\
& \mid \text { Ico } f \leftarrow \sum_{n=1}^{N} I_{n} \cdot \cos \left[\frac{2 \cdot \pi \cdot f}{N} \cdot(N-n)\right] \\
& I s i \underset{f}{I_{n=1}^{N}} I_{n} \cdot \sin \left[\frac{2 \cdot \pi \cdot f}{N} \cdot(N-n)\right] \\
& U c o \leftarrow \sum_{n=1}^{N} U_{n} \cdot \cos \left[\frac{2 \cdot \pi \cdot f}{N} \cdot(N-n)\right] \\
& U_{s i} \leftarrow \sum_{n=1}^{N} U_{n} \cdot \sin \left[\frac{2 \cdot \pi \cdot f}{N} \cdot(N-n)\right] \\
& Q_{f} \leftarrow \frac{2^{2}}{N^{2}} \cdot\left(I^{c o} \dot{f}^{U s i}{ }_{f}^{-I s i} \dot{f} U c o f\right) \\
& Q \leftarrow \sum_{f=3}^{6} Q_{f}
\end{aligned}
$$

Fig. 4. MathCAD software module for Fourier transform realization in the protection relay against SEF

The results of the mathematical modelling of the protection method in the case of SEF show that the total reactive power of the harmonics depends on the instantaneous value of the phase voltage at the time of the fault. The highest value of reactive power occurs when the phase voltage $\left(u_{f}\right)$ reaches the amplitude value (Fig. 5,a,c), and the least one - when reaching the zero value (Fig. 5,b,d). These power values (Fig. 5,c,d) are more than an order of magnitude and to be taken into account when selecting the set value for the comparator $Q_{T}$.

The results of the mathematical simulation of the relay operation at arc short circuits to the ground, the first of which arose at the amplitude value of the phase voltage, and the second one at zero, are shown in Fig. 6. Character of change of voltage $3 u_{0}$ - in Fig. 6,a, of the current $3 i_{0}$ and its derivatives $\mathrm{p}\left(3 i_{0}\right)-$ in Fig. $6, b$ and of the contacts of the relay output organ - in Fig. 6,c. In both cases, a clear relay operation was obtained.
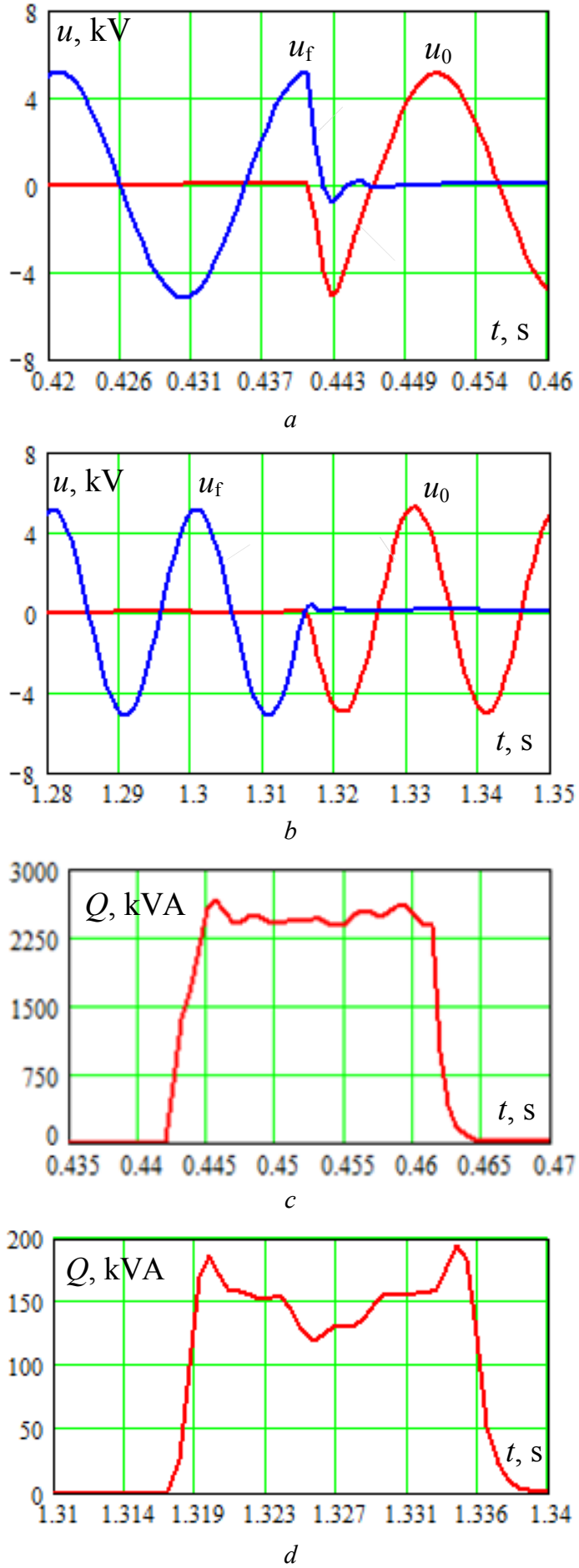

Fig. 5. Results of calculations of reactive power $(c, d)$ at occurrence of SEF at maximum $(a)$ and minimum $(b)$ values of phase voltage

The simulation of the operation of the protection relay under the conditions of five-fold undercompensation and overcompensation of the capacitive current, as well as at SEF in the protection zone and outside the protection zone, confirmed the correct and reliable operation of the relay. 


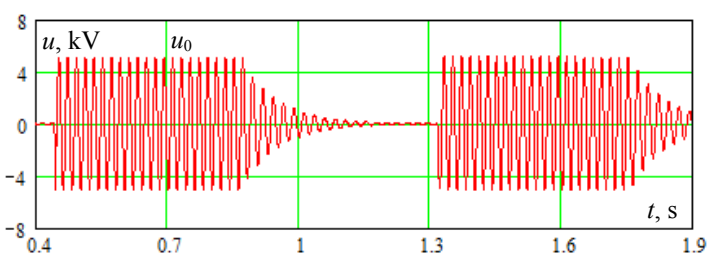

$a$

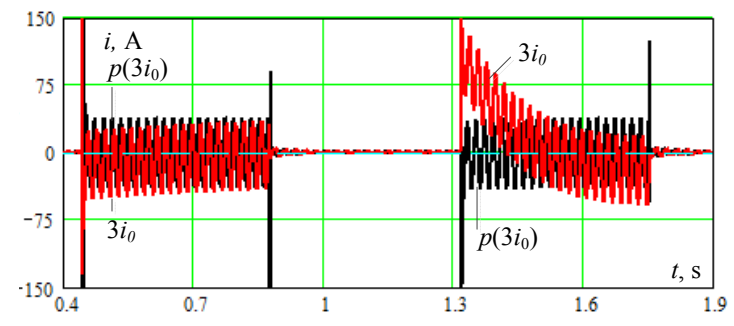

$b$

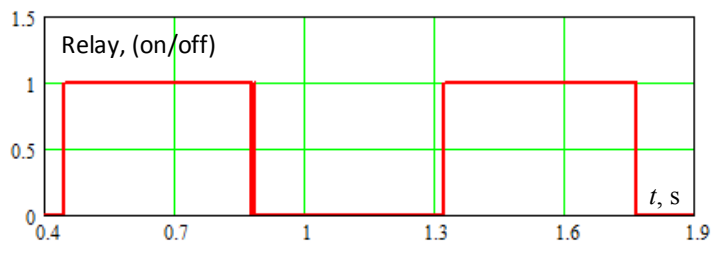

$c$

Fig. 6. Results of modelling the behavior of the protection relay at SEF with different aperiodic components in $3 i_{0}$

The prototype of protection according to the algorithm shown in Fig. 3 was implemented on the basis of microcontroller STM32F4Discovery. Its satisfactory operation in the case of SEF was obtained on the physical model of the compensated electrical network with voltage of $0.4 \mathrm{kV}$, as well as inputting current and voltage signals of zero sequence which were recorded by digital loggers in the real network at SEF.

The results of simulations and experiments confirm the possibility of implementation of the developed protection in the operating electrical networks.

\section{Conclusions.}

1. The results of mathematical modelling show that in compensated electrical networks at phase-to-earth fault, the reactive power of the damaged connection, which is found using harmonic components extracted from the current and voltage of zero sequence for frequencies greater than 100$150 \mathrm{~Hz}$, is positive regardless of the degree compensation of the capacitive current by the reactor, which can be the basis for the operation of selective protection.

2. A method of selective protection of the electrical network against phase-to-earth fault has been developed, using which, in order to reduce the influence of aperiodic components, first the derivatives of currents and voltages of the zero sequence are obtained, and then by means of the Fourier transform, a number of harmonic orthogonal components are extracted from each of them. which the reactive power is calculated and their total sum is found, and if it exceeds the specified one, the output organ is triggered.
3. The reliability of the developed method of selective protection is confirmed by the presented results of mathematical modelling and verification of the prototype operation at the laboratory stand, as well as by means of field signals recorded by digital registrars at SEF at operating substations.

\section{REFERENCES}

1. Shafiq M., Kiitam I., Taklaja P., Kütt L., Kauhaniemi K., Palu I. Identification and location of PD defects in medium voltage underground power cables using high frequency current transformer. IEEE Access, 2019, vol.7, pp. 103608-103618. doi: 10.1109/ACCESS.2019.2930704.

2. Marciniak L. General earth fault protection for $\mathrm{MV}$ networks using wavelet decomposition and Bayesian criterion. E3S Web of Conferences, 2019, vol.84, p. 02007. doi: 10.1051/e3sconf/20198402007.

3. Habrych M. Comparative performance study of the Hall sensor based directional ground fault protection in MV mining network with ineffective earthing. Przeglad Elektrotechniczny, 2016, no.8, pp. 251-254. doi: 10.15199/48.2016.08.65.

4. Kavaskar S., Mohanty N.K. Detection of high impedance fault in distribution networks. Ain Shams Engineering Journal, 2019, vol.10, no.1, pp. 5-13. doi: 10.1016/j.asej.2018.04.006.

5. Torres V., Guardado J.L., Ruiz H.F., Maximov S. Modeling and detection of high impedance faults. International Journal of Electrical Power \& Energy Systems, 2014, vol.61, pp. 163-172. doi: 10.1016/j.ijepes.2014.03.046.

6. Daqing Hou. Detection of high-impedance faults in power distribution systems. 2007 Power Systems Conference: Advanced Metering, Protection, Control, Communication, and Distributed Resources, Clemson, SC, 2007, pp. 85-95. doi: 10.1109/PSAMP.2007.4740902.

7. Marciniak L. Identyfikacja zwarć doziemnych wysokorezystancyjnych w sieciach średnich napięć. Przegląd Elektrotechniczny, 2015, no.8, pp. 185-189. (Pol). doi: 10.15199/48.2015.08.45.

8. Syvokobylenko V.F., Lysenko V.A. Mathematical modeling of new algorithms for single-phase earth faults protection in a compensated electrical network. Problemele Energeticii Regionale, 2019, no.1-2(41), pp. 1-11. doi: 10.5281/zenodo.3239135.

9. Syvokobylenko V.F., Lysenko V.A. Microprocessor selective protection from the phase to the earth fault in electric networks with Petersen coil in neutral. Technical Electrodynamics, 2019, no.2, pp. 54-62. (Rus). doi: 10.15407/techned2019.02.054.

10. Marciniak L. Określenie nastaw zabezpieczenia ziemnozwarciowego z falkowymi kryteriami działania. Przeglad Elektrotechniczny, 2014, no.6, pp. 261-264. (Pol). doi: 10.12915/pe.2014.06.52.

Received 11.10.2019

V.F. Syvokobylenko ${ }^{1}$, Doctor of Technical Science, Professor,

V.A. Lysenko ${ }^{1}$, Candidate of Technical Science,

${ }^{1}$ Donetsk National Technical University,

2, Shybankova Square, Pokrovsk, Donetsk region, 85300,

Ukraine,

e-mail: svf1934@gmail.com, viktor.lysenko@donntu.edu.ua

How to cite this article:

Syvokobylenko V.F., Lysenko V.A. Multifrequency protecting method against earth-faults of phase in the compensated electric networks. Electrical engineering \& electromechanics, 2020, no.1, pp. 56-60. doi: 10.20998/2074272X.2020.1.09. 